\title{
開心手術症例に括けるコイル加熱型連続心拍出量測定装置, 混合静脈血酸素飽和度測定装置の有用性について
}

\author{
鹿野直幸 ${ }^{1}$ 久保田浩光 ${ }^{1}$ 桜井 勝 $^{1}$ 赤池祝昭 $^{1}$ 金子ゆかり ${ }^{1}$ \\ 久保田充稔 ${ }^{1}$ 廣瀬善嗣弘 ${ }^{2}$ 矢部順 ${ }^{2}{ }^{2}$ 香内信明 ${ }^{2}$
}

\begin{abstract}
要 旨
連続心拍出量測定 $(\mathrm{CCO})$ ，混合静脈血酸素飽和度 $\left(\mathrm{S}_{\bar{v}} \mathrm{O}_{2}\right)$ の両方を連続表示するモニターリン グシステム(Vigilance)を用い，人工心肺装着下の開心術例64例を対象とし検討を行った。 Baxter 社製 CCO スワンガンツカテーテルを肺動脈内に挿入・留置し， $\mathrm{CCO}$ と $\mathrm{S} \overline{\mathrm{v}} \mathrm{O}_{2}$ を48時間に わたって持続的に湘定した。

開心術直後の血行動態は従来考えられていたように, $\mathrm{S}_{\bar{v}} \mathrm{O}_{2}$ と $\mathrm{CCO}$ の変化は必ずしも相関せ ず，様々な原因から解離した变化を示した。従来のスワンガンツカテーテルを用いた管理に比 し，血行動態を迅速かつ的確な把握を可能とする点で有用性は高い。しかて， $\mathrm{S}^{2} \mathrm{O}_{2}$ はCCOに比 し迅速に反応するといら報告はなされているものの, $\mathrm{S}_{\bar{v}} \mathrm{O}_{2}$ のみの変化による患者管理には注意 を必要とすることが示された。
\end{abstract}

Key words : $\mathrm{CCO}, \mathrm{S}_{\bar{v}} \mathrm{O}_{2}$, Vigilance

\section{I .はじめに}

スワンガンツカテーテル法による心拍出量の測 定は血行動態管理において重要なものとなってい $ろ^{1-3)}$ 。しかし，従来のスワンガンツカテーテル法 では血行動態の変化に即応できず，体外循環を行 らための情報として, 他のパラメーターに頼らざ る得ない。しかし，連続心拍出量測定(以下， $\mathrm{CCO})$ ，混合静脈血酸素飽和度 (以下, $\left.\mathrm{S}^{2} \mathrm{O}_{2}\right)$ の両方 を連続して表示する Continuous thermodilution system(Vigilance)を用いることにより，血行動態 を連続的に把握することが可能となり，その有用 性に関する報告も多い ${ }^{4-6)}$ 。ただし，体外循環に伴 ら温度変化， $\mathrm{Hb}$ 濃度の低下，体位変換，カテュラ ミンの増減など, $\mathrm{CCO}$ と $\mathrm{S}_{\bar{v}} \mathrm{O}_{2}$ に及ぼす影響につい て検討がなされていない。今回，当施設での使用 経験を踏まえ， $\mathrm{CCO}$ と $\mathrm{SvO}_{2}$ の両者を連続的に表示 する事の有用性と問題点拉よび臨床像について検

\section{1. 板橋中央総合病院 臨床工学科}

2. 同循環器内科
討を行った。

\section{II. 対 象}

平成 6 年 6 月から平成 7 年11月に，当院におい て人工心肺装着下で手術を受けた 64 例(CABG 44 例，弁置換術16例，CABG+弁置換術 1 例，その他 3 例：男性38例，平均年齢65歳)を対象とした(表 $1)$ 。

\section{III. 方 法}

\section{CCOスワンガンツカテーテルの挿入}

麻酔導入前に Baxter 社製 CCO スワンガンツカ テーテルを, 右内頸静脈より肺動脈内に挿入留置 した。Vigilanceの校正のため身長，体重，肺動脈 血の $\mathrm{Hb}$ 濃度および $\mathrm{Ht}$ 值, 肺動脈血酸素飽和度を 入力するとともに $\mathrm{CCO}$ と $\mathrm{SvO}_{2}$ の測定を開始し， 48時間にわたって持続的に行った。

\section{2. 体温の測定}

体温は食道，尿道，直腸および皮底にデジタル 温度計Mon-a-therm(Model 6510)を使用し，それ ぞれの温度变化を測定した(図 1)。また，体外循 環中の冷却・復温は食道温度, 深部温度は直腸温 
表 1 患者背景

\begin{tabular}{|c|c|c|c|c|}
\hline & 冠動脈バイパス術 & 弁置換 & 冠動脈バイパス術十弁置換 & 角 その他 \\
\hline 症例数 (例) & 44 & 16 & 1 & 3 \\
\hline $\begin{array}{l}\text { 性別男(人) } \\
\text { 女(人) }\end{array}$ & $\begin{array}{l}30 \\
14\end{array}$ & $\begin{array}{r}6 \\
10\end{array}$ & $\begin{array}{l}0 \\
1\end{array}$ & $\begin{array}{l}1 \\
2\end{array}$ \\
\hline 年歯 （歳） & $66 \pm 10$ & $61 \pm 10$ & 77 & $66 \pm 6$ \\
\hline 身長 （cm） & $160.4 \pm 9.2$ & $152.3 \pm 6.2$ & 150 & $158.3 \pm 6.6$ \\
\hline 体重 （kg） & $58.2 \pm 11.0$ & $47.2 \pm 10.8$ & 55.0 & $64.3 \pm 0.6$ \\
\hline
\end{tabular}

度を指標とした(図 2)。

3. $\mathrm{Hb}$ の測定

$\mathrm{Hb}$ の測定は 1 時間おきに血液ガスの測定と同時

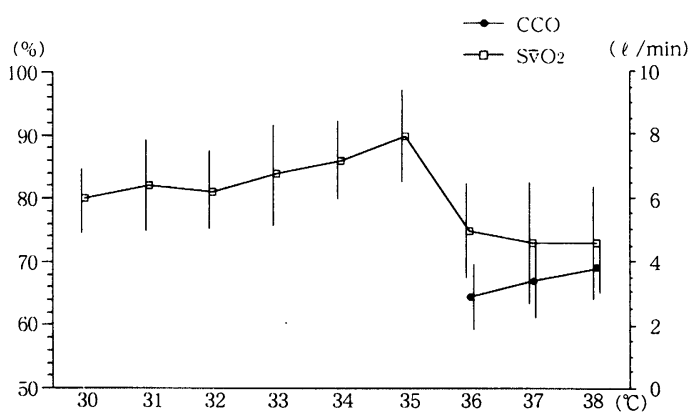

図 1 体温の变動

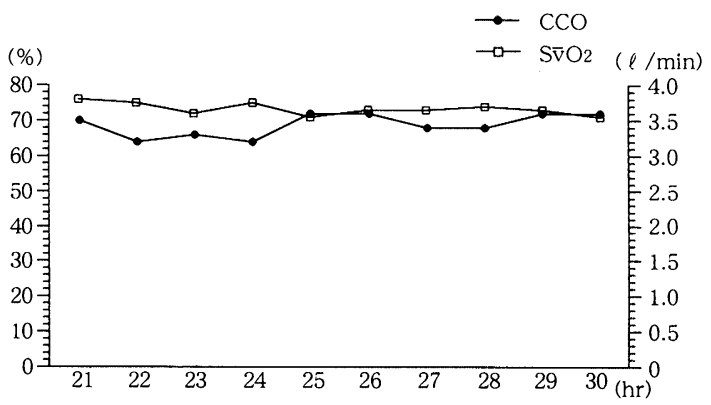

図 2 温度の均一化

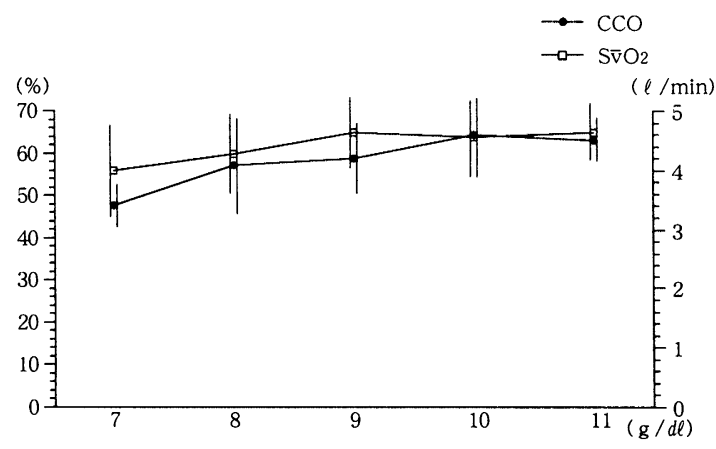

図 $3 \cdot \mathrm{Hb}$ の変動
に行った(図 3)。

\section{4. カテコラミンの影翠}

ドブタミン，ドバミンは血行動態および全身状 態を考慮し適宜減量した(図 4)。

\section{IABP の影響}

IABPはBaxter 社製Datascope system/97を使用 し，アシスト比は血行動態が 3 時間安定したとこ ろで設定変更を行った(図 5 )。

\section{6. 気管内吸引の影響}

気管内吸引は術後覚醒前で明らかな心不全を認 めない例では10秒以内で行い，その前後で経時的

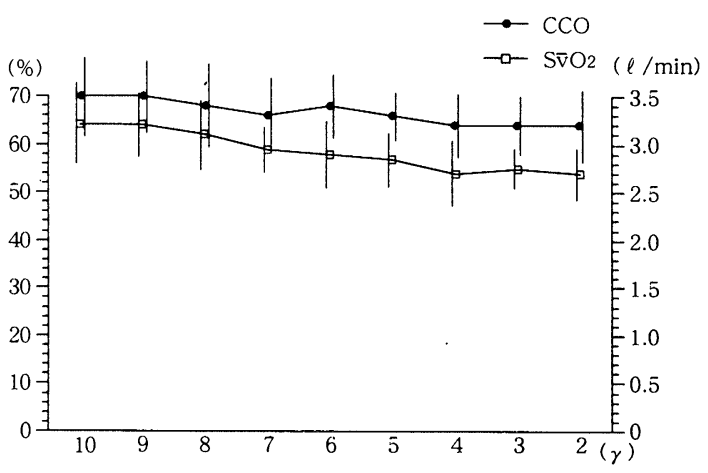

図 4 カテコラミンの影響

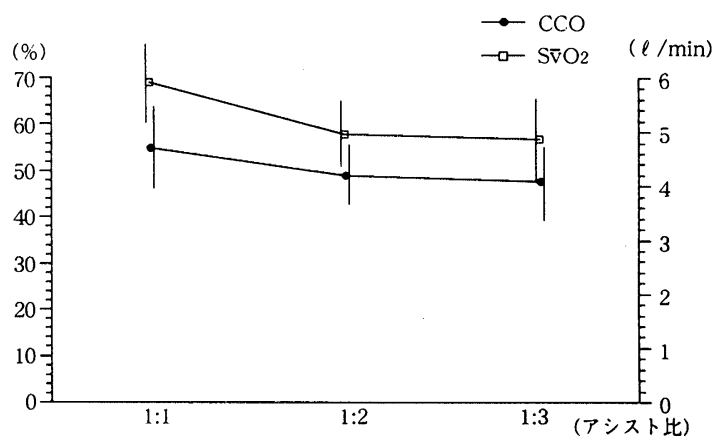

図 5 IABPの影響 
変化を観察した(因 6)。

\section{N. 結 果}

カテーテルの㨂入は容易で，従来のスワンガン ツカテーテルを用いた管理と何ら特別の処置を必 要とせず，血栓・塞栓症などの合併症も認めな かった。

体温の変動による $\mathrm{CCO}$ と $\mathrm{S}_{\mathrm{v}} \mathrm{O}_{2}$ の変化は，体外 循環離脱後 36 C以上では, $\mathrm{CCO}$ が徐々に増加した のに比し $\mathrm{S}_{\bar{v}} \mathrm{O}_{2}$ は低下した(図 1)。また, $\mathrm{S}^{2} \mathrm{O}_{2}$ は36 Cからは増加しはじめ末梢温度が中心温度と均一 化したところからは，両者はパラレルに推移した (図 2)。Hbの変動はHb $7 \mathrm{~g} / \mathrm{d} \ell$ か $59.5 \mathrm{~g} / \mathrm{d} \ell$ の 間では両者は異なった变動を示したが, $10 \mathrm{~g} / \mathrm{d} \ell$ 以上ではパラレルに推移した(図 3)。カテコラミ ンの減量は, $10 \gamma$ から 6 rでは $\mathrm{CCO}, \mathrm{Sv}_{2}$ ともパ ラレルに推移するが， $6 r$ 以下では $\mathrm{S} \overline{\mathrm{V}} \mathrm{O}_{2}$ のみ鋭敏 な変化を示した(図 4 )。IABP使用時では，CCOは アシスト比にかかわらずほぼ一定であったが，

$\mathrm{S}_{\bar{v}} \mathrm{O}_{2}$ はアシスト比の変更と共に低下を示した(図 5 )。気管内吸引の影響は, 約10秒間施行した直後 に $\mathrm{S}_{\bar{v}} \mathrm{O}_{2}$ の低下を認めたが，CCOは10分遅れて低下 し回復も同様に10分の遅延を認めた。同様に体位 変換はCCOにほとんど影響しないのに比し $\mathrm{S}_{\bar{v}} \mathrm{O}_{2}$ では低下傾向を示した(図6)。

\section{V. 考察}

開心術直後の血行動態は，従来考えられていた よらに $\mathrm{CCO}$ と $\mathrm{S}_{\mathrm{v}} \mathrm{O}_{2}$ の変化は必ずしも相関せず， 様々な原因から解離した変化を示しだフ。これらの 因子としては心拍出量, ヘモグロビン量, 動脈血 酸素飽和度，酸素消費量があげられる。これら変

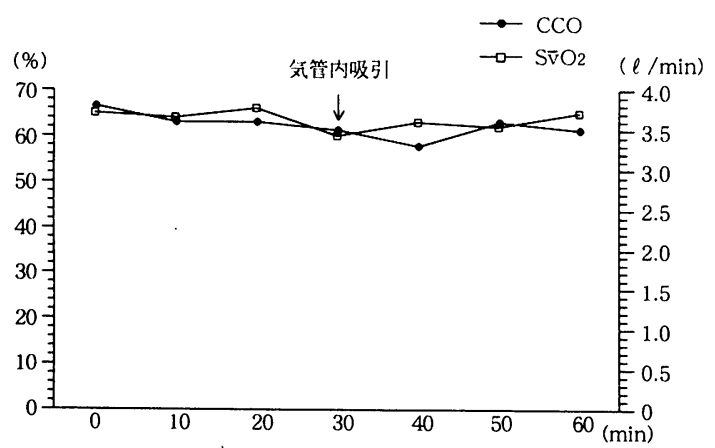

図 6 気管内吸引時
数間の相互関係，およびそれらの $\mathrm{S}_{\bar{v}} \mathrm{O}_{2}$ に対する影

響をフィック方程式を手直ししたもので示す。 $\mathrm{VO}_{2}=\mathrm{CO} \times \mathrm{Hb} \times 13.8 \times\left(\mathrm{SaO}_{2} \times \mathrm{S}_{\bar{v}} \mathrm{O}_{2}\right)$ $\dot{\mathrm{VO}}_{2}$ : 酸素消費量 $\mathrm{CO}:$ 心拍出量 $\mathrm{Hb}$ : ヘモグロビン量 $\quad 13.8:$ K因子 $\mathrm{SaO}_{2}$ : 動脈血酸素飽和度 $\mathrm{S} \mathrm{O}_{2}$ : 静脈血酸素飽和度 以上から $\mathrm{SvO}_{2}$ の变数は酸索供給变数 $(\mathrm{CO}, \mathrm{Hb}$, $\left.\mathrm{SaO}_{2}\right)$ の変化之正比例し，酸素消費量に反比例する ために，多数の因子の影響で違った値を示す可能 性があり， $\mathrm{Sv}_{2}$ のみで臨床的判断をくだすことは 難しい。

体温の変動についても同様に, $\mathrm{S}_{\bar{v}} \mathrm{O}_{2}$ は酸化 $\mathrm{Hb}$ 解離曲線に対する血液温度変化の影響で CCO とは 異なった変動を示した。また, 術後の心予備力が 低下している状態では，有効酸素を摄取すること に制約を受け， $\mathrm{S}_{\bar{v}} \mathrm{O}_{2}$ が低值を示したと思われる。

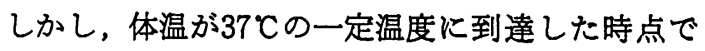
は, $\mathrm{S}_{\bar{v}} \mathrm{O}_{2}$ と $\mathrm{CCO}$ は変化が少なく一定であったよう に, 温度に $\mathrm{S}_{\bar{v}} \mathrm{O}_{2}$ は容易に追従するが, 開心術に伴 ら冷却・復温時には注意を要する

$\mathrm{Hb}$ が体外循環で急速希釈された場合に, 酸素運 搬能の低下を酸素運搬量を増加させることで代㑮 する。しかし，心予備力が低下しHbの变化を代償 出来ない場合, 過剩の酸素摄取が起き, $\mathrm{S} \overline{\mathrm{V}} \mathrm{O}_{2}$ は $\mathrm{Hb} 7 \mathrm{~g} / \mathrm{d} \ell$ から $9 \mathrm{~g} / \mathrm{d} \ell$ の間では低值に表示され やすく，体外循環を行ら場合には充分な注意を要 する。また，開心術症例のように血行動態が不安 定になりやすい場合に，カテコラミンの減量や IABP の設定値の変更にともなら変化を迅速に把 握するために， $\mathrm{S}_{\overline{2}} \mathrm{O}_{2}, \mathrm{CCO}$ の連続的モニターする ことの有用性は高いと思われるが， $\mathrm{S}^{2} \mathrm{O}_{2}$ とCCOの 值は計算プログラム上 3 分から 6 分の遅れが生じ るため, 血行動態が急速に変動している場合 $\mathrm{CCO}$ はその時点に拈㺭る心拍出量を正確に表示しえな い。この遅れに関しては今後の検討課題である。

\section{V. 結 論}

開心術後の患者の管理に際し, $\mathrm{CCO}$ と $\mathrm{S}^{\circ} \mathrm{O}_{2}$ の両 者を連続的に表示する事の出来る本装置は，数分 の達れは伴らものの, 従来のスワンガンツカテー テル法と比し，血行動態を迅速かつ的確に把握す ることが可能となり，有用性が高いことが示唆さ れた。しかし， $\mathrm{S}_{\bar{v}} \mathrm{O}_{2}$ はCCOに比し迅速に反応する 
といら報告”はなされているものの，多因子に影響 される $\mathrm{SV}_{2}$ は血行動態とは異なった变化をするた め注意を必要とする。

\section{参考文献}

1 ) Swan, H. J. C., Ganz, W., Forrester,J. et al. : catheterization of the heart in man with the use of a flow-directed balloon tipped catheter. N. Engl. J. Med., 283;447,1970.

2) Gantz, W., Donoso, R., Marcus, H. S. et al. : A new technique for mersurement of cardiac output by thermodilution in man. Am. J. Cardio., 27;392,1971.

3) Wessel HU, Paul MH, James GW et al. : Limitations of thermaldilution curves for cardiac output determinations. J Appl Physiol 30;643-652,1971.
4）佐藤正暢，他：連続的酸素飽和度測定装置の検討. 体外循環技術，22(2)；38-41,1996.

5 ）安田 剛, 他：開心術における連続心拍出量湘定装 置の使用経験. 体外循環技術, 21(1);93-95,1995.

6）近藤清廉，他：急性心筋梗塞患者管理における新し い連続心拍出量測定装置の有用性. Therapeutic Research, 16(8);2496-2498.1995.

7）片山勝之, 他：開心術症例における連続心拍出量之 混合静脈血酸素飽和度同時測定の有用性について. 臨 林モニター, 1(5);87-88,1994。

8）宮本浩三，他：体外循環中における $\mathrm{S}^{2} \mathrm{O}_{2}$ の变動につ いて. 体外循環技術, 20(1);37-39,1994.

9 ）近藤清廉, 他：重症心疾患患者管理における連続心 拍出量 - 混合静脈血酸素飽和度湘定装置の有用性. 臨 林モニター，1(6);54,1995. 